\title{
POST-COMMUNISM STRUCTURAL CHANGES OF THE ROMANIAN FORESTRY SECTOR
}

Forests cover $28 \%$ of the land area of Romania and, they are important from the ecological, economic and social perspectives. Political initiatives to restore property to its pre-nationalization (1948) forest owners became a reality, after the fall of communism. Compared to the other former communist countries from Central and Eastern Europe, the forest restitution process in Romania took a longer time and has been legally implemented via three successive restitution laws in a period of 15 years: Law 18/1991, Law $1 / 2000$ and Law 457/2005. By the successive implementation of these forest restitution laws, the total forest area restituted to the non-state forest owners reached 3.15 million ha at the beginning of 2017, representing about half of the total forest area in Romania. The institutional changes in the forestry sector have been politically influenced (both by the Government and European Union) and not always responsive to the sector needs, realities and evolution. Whilst during the communist period, all typical sectoral functions such as regulatory, supervisory, management and ownership were under the responsibility of the same entity - the Ministry of Forests, in early $1990 \mathrm{~s}$ the regulatory and supervisory functions of the state were separated from the management function as the National Forest Administration (NFA)-Romsilva was established as the management entity of state forests, mainly with a commercial mandate. The move of the Department of Forests (the public authority responsible for forests in Romania) under different ministries in the last three decades was accompanied by many changes of the subordinated units and disruptions in the normal activity of its staff. Regarding the forest control and supervisory functions at regional level, 7 regional Forest Inspectorates were established in 1999, their number being increased to 16 in 2001. After 2003 they have had a tumultuous evolution, with several changes of mission and subordination and in 2015, the Forest Inspectorates were transformed into Forest Guards. A significant institutional milestone in the post-communist development of the forestry sector in Romania was the establishment of the first "private" forest districts (administrative/management legal entities for non-state forests, similar to those of NFA-Romsilva) in 2002: their number reached 145 in 2017, managing more than 1.7 million ha of forests. The radical change in forest ownership continues to pose a high pressure on the restructuring of the forest institutions, administration and management structures. It is expected that the decentralisation and reduction of state role in forest administration and management will continue in the next decade.

Keywords: forest restitution; forestry sector; Romania; structural changes.

Introduction. Forests cover $28 \%$ of the land area of Romania (circa 6.56 million ha) (INS, 2018) and the country is famous in Europe for its large tracts of natural and old growth forests (Abrudan et al., 2009). Forestry sector is an important contributor to the Romanian economy: more than 200;000 people are employed in forest administration and downstream wood harvesting and processing industries; including furniture production (INS, 2018). According to the National Institute of Statistics; the annual export of wood and wood products has increased continuously in the last decade; and in the last 3 years it exceeded 3.5 billion Euro (of which furniture export represented more than 2 billion Euro) (INS, 2018). Non-timber forest products also represent an important source of income for some rural communities.

Political initiatives to restore property to its pre-nationalization (1948) forest owners became a reality; after the fall of communism. Compared to the other former communist countries from Central and Eastern Europe; the forest restitution process in Romania took a longer time and has been legally implemented via three successive restitution laws in a period of 15 years: Law 18/1991; Law1/2000 and Law
457/2005. The changes in forest ownership as well as the transition from a centrally planned to a free-marked oriented economy have determined significant institutional changes in the Romanian forestry sector. The aim of the present paper is to briefly asses the main forest ownership and institutional post-communist changes in the Romanian forestry sector and to identify the main challenges and priorities for its future development.

Post 1990 forest ownership changes. After the fall of communist regime in Romania; the Government embarked in 1991; on a program of land restitution (Poynton et al., 2000). As an initial measure; under Law 18/1991; up to 10 hectares of agricultural land and 1 ha of forest land was restituted to each pre-1948 (nationalization year) former owner or his/her descendants. As a consequence; $353 ; 630$ hectares of forests were restituted to around 400;000 individual owners. Most of the recipients of these small areas of up to 1 ha of forest land (even if the forest area owned before 1948 nationalization was larger) were poor and; therefore; primarily interested in cashing benefits from their forest (Poynton et al., 2000).

In 2000; another land restitution law was passed by the Romanian Parliament (Law 1/2000). According to this law

\section{Інформація про авторів:}

Abrudan Ioan Vasile, Prof., dr., Faculty o Silviculture and Forest Engineering. Email: abrudan@unitbv.ro

Цитування за ДСтУ: Абрудан І. В. Post-communism structural changes of the Romanian forestry sector. Науковий вісник НЛТУ України. 2019, т. 29, № 10. С. 18-21.

Citation APA: Abrudan, I. V. (2019). Post-communism structural changes of the Romanian forestry sector. Scientific Bulletin of UNFU, 29(10), 18-21. https://doi.org/10.36930/40291002 
all community; town and communal forests had to be restituted to their former owners. Also; the restitution area limit was 10 ha for individuals and 30 ha for churches; irrespective of their ownership size before 1948 nationalization. Finally; according to Law 427 from 2005; all non-state forest lands had to be restituted to their former owners or legal descendants (individuals or private/non-state entities). By the successive implementation of these three forest restitution laws; the total forest area restituted to the non-state forest owners reached $3 ; 15$ million ha at the beginning of 2017 (Table 1); representing about half of the total forest area in Romania.

Table 1. Restituted area by categories of forest owners at 01.01.2017 (Source: Ministry of Waters and Forests)

\begin{tabular}{|l|c|c|c|}
\hline \multicolumn{1}{|c|}{ Type of ownership } & $\begin{array}{c}\text { Validated area } \\
\text { to be restituted (ha) }\end{array}$ & $\begin{array}{c}\text { Area put in } \\
\text { possession (ha) }\end{array}$ & $\begin{array}{c}\text { Validated area but not put } \\
\text { in possession yet (ha) }\end{array}$ \\
\hline Individuals (physical persons) & 1.402 .338 & 1.299 .147 & 103.191 \\
\hline Administrative territorial units (towns; villages) & 946.991 & 933.953 & 13.038 \\
\hline Education institutions (schools) & 7.511 & 7.325 & 186 \\
\hline Churches & 129.492 & 123.493 & 5.999 \\
\hline Associative legal entities (undivided common ownership) & 788.694 & 768.176 & 20.518 \\
\hline Romanian Academy & 16.887 & 16.412 & 475 \\
\hline Elias Foundation & 2.989 & 2.006 & 983 \\
\hline \multicolumn{1}{|c|}{ Total } & $\mathbf{3 . 2 9 4 . 9 0 2}$ & $\mathbf{3 . 1 5 0 . 5 1 2}$ & $\mathbf{1 4 4 . 3 9 0}$ \\
\hline
\end{tabular}

However; as in 1948 the state owned only $28 \%$ of the forest area; whilst individuals (physical persons) owned around $23 \%$ (Poynton et al., 2000); it is obvious that not all the non-state forests were claimed back by the former owners or their descendants (due to various reasons: death; emigration etc.) and also that for some of the claimed area; the deeds or legal ownership proofs were not provided and the area was not validated for restitution. Due to such situations and according to the existing legislative framework it is expected that the state will continue to own and manage almost half of the Romanian forest area; whilst the nonstate ownership will slightly exceed $50 \%$ of the country's forests.

Post 1990 institutional changes in the Romanian forestry sector. The institutional changes in the Romanian forestry sector have been very dramatic after the 1989 political changes. During the communist period; all typical sectoral functions: regulatory; supervisory; management and ownership were under the responsibility of the same entity - the Ministry of Forests. In early 1990 the regulatory and supervisory functions of the state were separated from the management function as the National Forest Administration (NFA)-Romsilva was established as the management entity of state forests; mainly with a commercial mandate (Poynton et al., 2000).

The Department of Forests (within the Ministry of Environment in the period 1990-2001; the Ministry of Agriculture in the period 2001-2010; again in the Ministry of Environment and Forests in the period 2010-2017; and within the Ministry of Waters and Forests since 2017) has been the public authority responsible for forests in Romania.
The move of the Department of Forests under different ministries in the last three decades was accompanied by many changes of the subordinated units and disruptions in the normal activity of its staff. Irrespective of these changes; the regulatory and supervisory/support functions have remained under the responsibility of the Department of Forests. The activity of the Department of Forests has been affected by the reduced capacity and physical resources to undertake its roles due to understaffing and budgetary constraints (Abrudan et al., 2009).

Regarding the forest control and supervisory functions; as a measure to prepare the second wave of forest restitution; 7 regional Forest Inspectorates were established in 1999; their number being increased to 16 in 2001. Their function was to enforce at regional level the control and supervision/support functions of the public authority for forests. Due to the Cabinet re-organization; in spring 2003 the Forest Inspectorates were transferred to the National Environmental Guard within the National Authority for Control (totally separated from the public authority responsible for forestry) and left the Department of Forests without any territorial structures. In January 2004; 9 regional Forest Inspectorates were established mainly for providing extension services and implementation of EU SAPARD program and in 2005 they were re-attributed the control and supervisory function. After the move of the Forestry Department under the Ministry of Environment in 2010; in the year 2015; the Forest Inspectorates were transformed into Forest Guards and in 2017 they were transferred under the Ministry of Waters and Forests (Table 2).

Table 2. Milestones in the evolution of the Forest Inspectorates

\begin{tabular}{|c|l|}
\hline Year & \multicolumn{1}{|c|}{ Structural/functional milestone } \\
\hline 1999 & Establishment of 7 regional Forest Inspectorates \\
\hline 2001 & The number of regional Forest Inspectorates increased to 16 and they were moved under the Ministry of Agriculture \\
\hline 2003 & $\begin{array}{l}\text { Beginning of the implementation of a World Bank Project to support the Forest Inspectorates capacity building } \\
\text { (infrastructure and staff) }\end{array}$ \\
\hline 2003 & $\begin{array}{l}\text { The Forest Inspectorates are disbanded - their control functions and the staff are taken over by the Environmental Guard } \\
\text { (under National Authority for Control) }\end{array}$ \\
\hline 2004 & $\begin{array}{l}9 \text { territorial Forest Inspectorates are established mainly for providing extension services and implementation of EU SA- } \\
\text { PARD Program }\end{array}$ \\
\hline 2005 & The forest control and supervisory functions are taken back by the Forest Inspectorates \\
\hline 2010 & The Forest Inspectorates are moved under the Ministry of Environment and Forests \\
\hline 2015 & The Forest Guards are replacing the Forest Inspectorates \\
\hline 2017 & The Forest Guards are moved under the Ministry of Waters and Forests \\
\hline
\end{tabular}


As a consequence of the first post-1990 Forest Code (Law 26/1996); the National Forest Administration-Romsilva was established through the Government Decision 1112/1996; as a legal state-owned entity with an essentially commercial mandate; responsible for the administration and management of state forests. NFA-Romsilva replaced the previous public forest administration company (Autonomous Forest Administration created by Government Decision 1335/1990) (Abrudan, 2012).

The NFA-Romsilva administrates and manages the state forests and is a legal state-owned entity with a commercial mandate. In the last two decades NFA-Romsilva has undergone a significant restructuring and re-organization process especially as a consequence of the forest restitution; through which more than half of the Romanian forests have been transferred in non-state ownership. Nowadays; it has 42 branches and 342 forest districts and operates as a financially autonomous organization performing forest management and silvicultural operations; NFA-Romsilva also engages in non-timber forest products and services and is responsible for the management of protected forest areas (including Natura 2000 sites) and national parks; which have been functioning since early 2009 as distinct legal entities.

A significant institutional milestone in the post-communist development of the forestry sector in Romania was the establishment of the first "private" forest districts (administrative/management legal entities for non-state forests; similar to those of NFA-Romsilva) in 2002. Their number increased continuously in parallel with the forest restitution process (Figure 1); and in 2004 they established an umbrella association named Association of Forest Administrators from Romania (AAPR). According to the 2015 amendments to the last Forest Code (Law 46/2008) their name was changed in the "regime" forest districts and in 2017 their number reached 145; managing more than 1.7 million ha of forests (MWF, 2017).

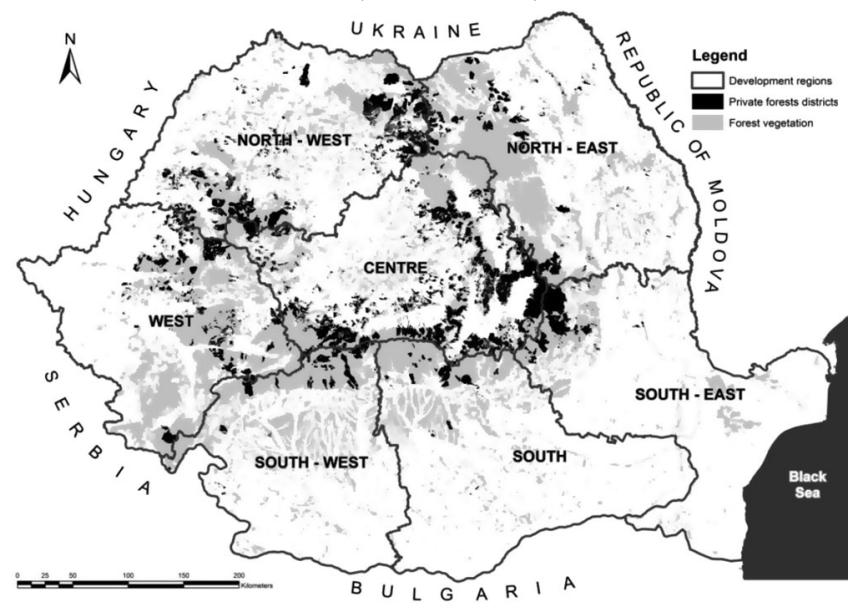

Figure 1. Forest area managed by non-state (private) forest districts (Abrudan, 2012)
The number of the non-state forest districts is expected to increase in the coming years; in parallel with the reduction of NFA-Romsilva forest districts; as a consequence of the restitution process.

In this ownership and structural context; the institutional strengthening of the Department of Forests should represent a priority for the development of the forestry sector. Proper staffing; training and the development of the IT infrastructure are vital in this respect. On the other hand; the capacity development of the Forest Guard should include staffing; endowment with the needed field equipment and training (e.g. communication; conflict management etc.)

While presently about half of the Romanian forests are in non-state ownership; the role and mandate of the NFARomsilva should be adapted to its new position in the Romanian forestry sector. The administrator of the state forests should reconsider its portfolio of activities and cope with the new challenges: non-state sector competition; Natura 2000; social responsibility; public scrutiny etc. At the same time; the non-state forest districts should increase their dialogue with the forest owners and develop new skills; including communication; marketing; project management etc. However; it is expected they will increase their power and influence in the forest sector at regional and national level as more than 1 million ha of non-state forests still managed by NFA-Romsilva on a contractual basis.

Conclusions. In post-1990 Romania; the forest restitution processes were politically decided and the institutional changes in the forestry sector have been politically influenced (both by the Government and European Union) and not always responsive to the sector's needs; realities and evolution. The radical change in forest ownership continues to pose a high pressure on the restructuring of the forest institutions; administration and management structures. Decentralisation and reduction of state role in forest administration and management will probably continue in the next decade.

\section{References}

Abrudan, I. V. (2012). A decade of non-state forest administration in Romania: achievements and challenges. International Forestry Review, 14(3),

https://doi.org/10.1505/146554812802646684 275-284.

Abrudan, I. V., Marinescu, V., Ionescu, O., Ioras, F., Horodnic, S. A. \& Sestras, R. (2009). Developments in the Romanian forestry and its linkages with other sectors. Notulae Botanicae Horti Agrobotanici Cluj-Napoca, 37(2), 14-21.

INS. (2018). National Institute of Statistics. Statistical Yearbook of Romania.

Ministry of Waters and Forests (MAP). (2017). Working Paper (Draft): National Forest Strategy 2017-2026, 63 p.

Poynton, S., Mitchell, A., Ionascu, Gh., Mckinnenn, F., Elliott, J., \& Abrudan, I. V. (2000). Economic evaluation and reform of the Romanian forestry sector. Editura "Pentru viata" Brasov, 138 p.

Іоан Васіле Абрудан

Трансільванський університет Брашова, м. Брашов, Румунія

\section{ПОСТКОМУНІСТИЧНІ СТРУКТУРНІ ЗМІНИ ЛІСОВОГО СЕКТОРУ РУМУНІЇ}

Ліси займають 28 \% від території Румунії і є важливими чинниками, які впливають на екологічні, економічні та соціальні перспективи. Після падіння комунізму політичні ініціативи щодо відновлення власності лісокористувачів до націоналізації (1948р.) було втілено в життя. Порівняно з іншими колишніми комуністичними країнами Центральної та Східної Свропи процес реституції лісу в Румунії тривав довше і був законно впроваджений через три послідовні закони про реституцію впродовж 15 років: Закон 18/1991, Закон 1/2000 та Закон 457/2005. Внаслідок послідовного впровадження цих законів про 
реституцію лісів загальна кількість лісових ресурсів, що відшкодована власникам недержавних лісів, на початок 2017 р. сягала 3,15 млн га, що становить близько половини від загальної площі лісів Румунії. Інституційні зміни в секторі лісового господарства зазнали політичного впливу (як уряду, так і Свропейського Союзу), який не завжди відповідав потребам, реаліям та розвитку галузі. Хоча впродовж комуністичного періоду всі типові галузеві функції, зокрема регуляторні, наглядові, управлінські та майнові були під відповідальністю одного і того ж суб'єкта - Міністерства лісів, на початку 1990 р. регуляторні та наглядові функції держави було відокремлено від управлінських функцій, оскільки Національну лісову адміністрацію (НЛА) - Ромсільва - було створено як суб'єкт господарювання державних лісів, головно 3 комерційним мандатом. Перехід Департаменту лісів (державний орган, відповідальний за ліси в Румунії) у підпорядкування різних міністерств упродовж останніх трьох десятиліть супроводжувався багатьма змінами підпорядкованих підрозділів і порушенням нормальної діяльності його персоналу. Стосовно контролю за лісами та наглядових функцій на регіональному рівні, варто зазначити, що у 1999 р. було створено 7 регіональних лісових інспекцій, кількість яких збільшилася до 16 у 2001 р. Після 2003 р. вони зазнали бурхливого розвитку, з кількома змінами місії та підпорядкування, а у 2015 р. Лісові інспекції було реорганізовано в Лісову охорону. Значною інституційною віхою в період посткомуністичного розвитку лісового сектору Румунії було створення перших "приватних" лісових районів (адміністративних/управлінських юридичних осіб для недержавних лісів, аналогічних NFA-Romsilva) у 2002 р., їх кількість досягла 145 у 2017 р., впорядковуючи більш ніж 1,7 млн га лісів. Радикальні зміни у власності лісів продовжують створювати високий тиск на реструктуризацію лісових установ, адміністративних та управлінських структур. Очікують, що децентралізація та зменшення ролі держави в управлінні лісами продовжуватимуться і в наступному десятилітті.

Ключові слова: реституція лісу; сектор лісового господарства; Румунія; структурні зміни. 